\title{
Physicochemical and microbiological changes in gutted and ungutted red tilapia (Oreochromis ssp) stored in ice
}

\author{
Yaneth L. Ruíz-Osorio, Claudia M. Amorocho-Cruz, and Nelson Gutiérrez- \\ Guzmán
}

Facultad de Ingeniería, Universidad Surcolombiana, Ave. Pastrana Borrrero A.A 385 y 974, Neiva, Huila, Colombia.

\begin{abstract}
Y.L. Ruiz-Osorio, C.M. Amorocho-Cruz, and N. Gutiérrez-Guzmán. 2015. Physicochemical and microbiological changes in gutted and ungutted red tilapia (Oreochromis ssp) stored in ice. Cien. Inv. Agr. 42(2): 263-272. We assessed the degree of freshness of gutted and ungutted red tilapia (Oreochromis ssp) using physicochemical and microbiological analyses of samples of gutted red tilapia on days $0,3,5,8,11,14$ and 17 and of ungutted red tilapia on days $0,3,6,9,11$, 14 and 16. The total sample size was five fish stored in ice at temperatures between 0 and $4{ }^{\circ} \mathrm{C}$. Different methods were used to study the degree of freshness: $\mathrm{pH}$, water holding capacity (WHC) and microbiological analysis (aerobic mesophilic count). Once we obtained the results, a one-way analysis of variance (ANOVA) was used to determine possible correlations between the values of deterioration and the data obtained by other analysis methods. The one-way ANOVA showed that statistically significant differences $(\mathrm{P}<0.05)$ were found in almost all of the parameters analyzed throughout the storage times, indicating the loss of freshness in the fish. In the gutted fish, the firmness of the fillets and the whole fish presented the most noticeable statistically significant deterioration on day eight of storage, when the six logarithmic cycles of aerobic mesophilic bacteria counts were exceeded, and the fillets presented a statistically significant deterioration of the WHC. The ungutted fish began to lose freshness that limited the consumption of the food between the third and sixth day of storage, with aerobic mesophilic bacteria counts of $7.33 \pm 1.07$ Log CFU g ${ }^{-1}$ and 7.14 $\pm 1.60 \log ^{C F U ~ g}{ }^{-1}$, respectively. Similarly, significant decreases in firmness in the fillets and abdomen were noticed on the third day of storage.
\end{abstract}

Key words: Aerobic mesophilic bacteria, fishes, $\mathrm{pH}$, storage, water holding capacity, WHC.

\section{Introduction}

At death, fish muscles are entirely relaxed; the flesh is tender and flexible, and its texture is firm and elastic to the touch. After a short amount of time, the muscle tissue contracts and becomes

Received August 12, 2014. Accepted May 29, 2015.

Corresponding author: claudiamilena.amorocho@usco.edu.co rigid in what is known as rigor mortis, becoming an inflexible product (Huss, 1988). In addition to these tangible physical changes, following capture, fish begin to undergo autolytic and microbiological changes related to nutrition, the time following capture, size and the environmental conditions where the fish were caught (Sallam, 2007). These changes alter its chemical composition and, as mentioned by Pons-Sánchez-Cascado (2005) 
and Ocaño-Higuera et al. (2011), contribute to its deterioration and subsequent rejection by the final consumer. Another important aspect is that the rate of loss of quality depends directly on the species itself, as well as and the storage management and conditions (Olafsdottir et al., 1997; Rodríguez et al., 2004; García-Soto et al., 2013).

Autolytic degradation is a process by which the fish flesh is broken down by endogenous enzymes (Jain et al., 2007) present in the muscles and gut. Authors, such as Huss (1988), Pons-SánchezCascado (2005) and Massa (2006), all affirmed that when the fish dies, blood circulation terminates, stopping oxygen and nutrients from reaching the muscles. However, cellular activity continues for a short a time until the energy reserves, mainly glycogen and adenosine triphosphate (ATP), are depleted. These substances remain in the muscle cells after the fish's struggle to free itself once it is caught. In this process, in order to obtain more oxygen, anaerobic glycolysis takes place and breaks down the glycogen into glucose and lactic acid. The accumulation of lactic acid leads to a decreased level of muscle $\mathrm{pH}$ to the isoelectric point for myofibrillar proteins (this varies from species to species). The muscles are then denatured and lose their ability to retain water, fostering changes in the texture of the fish and a subsequent loss of quality.

The depletion of myofibrillar ATP favors the irreversible union of actin and myosin filaments (Massa, 2006), leading to rigor mortis (the loss of muscular flexibility and extensibility). The union of these two proteins leads to muscular contraction, which occurs for a few days and is subsequently reversed by the action of proteolytic enzymes that degrade some of the components of the muscle tissue (Massa, 2006; Jain et al., 2007).

Autolytic changes also involve proteolytic enzymes (Ayala et al., 2010; Li et al., 2013). These are responsible for the characteristic softening of the tissue (FAO, 1995; Hultmann and Rustad,
2007) as they hydrolyze proteins in the muscle, signaling that the flesh will soon deteriorate (Hultmann and Rustad, 2007).

In terms of microbiological degradation, although the muscle and internal organs of the recently captured fish are sterile, their skin, alimentary tract and gills contain a large number of bacteria (Adams and Moss, 1997; Barros-Velázquez et al., 2008). According to FAO (1995) and Gram and Huss (1996), the bacterial flora in a recently caught fish depends more on its environment when caught than on the species itself. Those caught in very cold, clean waters have fewer microorganisms than those caught in warm waters. According to FAO (1995), the presence of microorganisms on the skin surface may vary by a range of $10^{2}-10^{7}$

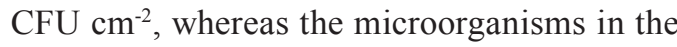
gills and intestines may reach $10^{3}-10^{9} \mathrm{CFU} \mathrm{g}^{-1}$, and these can extend to other tissues where the presence of nutritional substances and $\mathrm{pH}$ favors their development (Massa, 2006). This fosters a bacterial degradation of low-molecular weight constituents producing volatile metabolites (trimethylamine, ammonia, etc.). These, in turn, are responsible for a disagreeable smell and taste and the consequent sensorial rejection (FAO, 1995; Massa, 2006). However, $\mathrm{pH}$ value is not the only factor that favors the growth of microorganisms. Carbohydrates exist in fish in low concentrations to begin with, and they become exhausted moments before death. The lack of this substance means that bacteria on the fish's skin resort to using a soluble mixture of nitrogenous substances that are easily assimilated and produce a disagreeable smell and taste (Adams and Moss, 1997). Sharks and school sharks are considered elasmobranchs, containing high concentrations of urea, which leads to bacterial urease activity in the muscles that can produce ammonia very quickly, producing an acrid odor.

Currently, there is a huge demand for fresh foodstuffs that are subjected to rigorous safety regulations (Chebet, 2010). This has led the fishing industry and control organizations to develop and 
implement methods that allow the certification of the quality and safety of their products.

Freshness and quality in marine species is assessed based on the measurement of postmortem sensorial, physicochemical and microbiological changes (Ocaño-Higuera et al., 2011; Li et al., 2013). All three methods have been used to determine the freshness of a particular species (Pons-Sánchez-Cascado et al., 2006; Hernández et al., 2009). This agrees with Pons-Sanchez-Cascado (2005) in affirming that no one method is ever sufficient, and two methods are normally recommended: one to determine the loss of freshness if this has happened and another to determine the microbial deterioration.

The purpose of this paper was to assess the freshness of gutted and ungutted red tilapia (Oreochromis ssp) stored in ice using physicochemical and microbiological methods.

\section{Materials and methods}

\section{Sampling and storage conditions}

A total of 80 fish samples of commercial size (380-420 g) were bought from a fish factory at the Betania Reservoir, in the center-western part of the Huila Department, $35 \mathrm{~km}$ from the city of Neiva (Colombia). The department is responsible for the largest tilapia production in the country, supplying national and international markets. We worked with 40 fish with scales, gutted at the collection site and packed into expanded polystyrene cases, alternating layers of fish with layers of ice in a 1:1 ratio. Once packed, they were taken to a laboratory within an hour of purchase. The cases were then numbered and stored in a refrigerator with a temperature range of $0-4{ }^{\circ} \mathrm{C}$. The remaining 40 ungutted specimens were transported in the same conditions as the gutted fish. The gutted samples were analyzed on days $0,3,5,8,11,14$ and 17 according to the methodology by Simat et al. (2012), whereas the ungutted samples were tested on days $0,3,6,9,11,14$ and 16 .

\section{Moisture content analysis}

The moisture content of red tilapia was analyzed according to the method established by AOAC 950.46 (1997), where three containers with sea sand and a glass rod were dried in a kiln (HUMBOLDT MFG. CO, Elgin, Illinois, EE.UU) at 103 $\pm 2{ }^{\circ} \mathrm{C}$ for $24 \mathrm{~h}$. These were then tempered in a desiccator and weighed on an analytical balance. The value was established as $\mathrm{m}_{0}$. Ten grams of homogenized skinless sample was added using the glass rod, and the container with the sand, glass rod and sample were weighed again. This new value was established as $m_{1}$. The samples were then kept in the kiln at a temperature of $103 \pm 2{ }^{\circ} \mathrm{C}$ for $24 \mathrm{~h}$, after which the containers were tempered in a desiccator and weighed again $\left(\mathrm{m}_{2}\right)$. The moisture percentage is expressed in $\mathrm{g}$ of water per $100 \mathrm{~g}$ of sample.

\section{pH analysis}

The $\mathrm{pH}$ of fish muscle from just under the skin was analyzed. A homogenized fish-distilled water mixture was prepared using a ratio of 1:10 weight/volume using a T 18 ULTRA-TURRAX IKA Disperser Homogenizer, following the methodology of Fuentes et al. (2010) and Liu et al. (2013). The $\mathrm{pH}$ of the solution was determined using a WTW Portable digital pH-meter 31,5i model. These measurements were carried out in triplicate in order to obtain the $\mathrm{pH}$ value of tilapia.

\section{Water holding capacity analysis (WHC)}

The WHC was analyzed using the methodology of Owen et al. (1981), with modifications that consisted of placing a $0.3 \mathrm{~g}$ sample of meat between four filter papers previously dried in a kiln at 103 $\pm 2{ }^{\circ} \mathrm{C}$ for $10 \mathrm{~min}$. The paper was subsequently tempered in a desiccator and weighed, and the sample was placed between the four pieces filter paper and pressed between two approximately 20 $\mathrm{cm} \times 12 \mathrm{~cm}$ acrylic plates, under $10 \mathrm{~kg}$ pressure for 
$15 \mathrm{~min}$. The test was carried out with 4 replicates in order to average the final value.

\section{Microbiological analysis}

Samples of three different fish stored on ice were taken from each group to estimate the viable count. Ten grams of tilapia muscle was macerated with $90 \mathrm{~mL}$ of peptone water (Merck) for $4 \mathrm{~min}$. Serial dilutions were made, and $1 \mathrm{~mL}$ of each dilution was placed on a sterile plate using a pipette and seeded in depth in an agar Plate Count (PC) (Merck). The plates were incubated for 3 days at $30{ }^{\circ} \mathrm{C}$. In the microbiological analysis, we determined the aerobic mesophilic bacteria present in the deterioration of gutted and ungutted tilapia stored on ice at $0{ }^{\circ} \mathrm{C}$ to $4{ }^{\circ} \mathrm{C}$. On each day of the sampling, $10 \mathrm{~g}$ of muscle was taken from each tilapia. For the gutted tilapia, a transversal cut was made following the methodology of Hernández et al. (2009). In the ungutted tilapia, the cut was made on the fish's back, following the methodology of Pérez et al. (2002). Both samples were taken aseptically and placed in sterile bags, where they were homogenized with peptone water (Merck) according to the Colombian Technical Guide (GTC 78) (ICONTEC, 2002). Based on the homogenized sample $\left(10^{-1}\right.$ dilution of a stock solution), we prepared serial decimal dilutions according to Colombian Technical Norms NTC-4519 (ICONTEC, 2009) and NTC-4491-1
(ICONTEC, 2005), and Norm UNE EN -ISO 6887-3 (AENOR, 2004). One $\mathrm{mL}$ of each of the dilutions in duplicate was inoculated in agar PC (Merck). The plates were subsequently incubated at $30{ }^{\circ} \mathrm{C}$ in aerobic conditions for 3 days.

\section{Statistical analysis}

The significant differences in freshness parameters were tested using a one-way analysis of variance (ANOVA). Statistical Analysis System Software (STATGRAPHICS Centurion, XV. II version, StatPoint, Inc., USA) was used to carry out multiple range tests among the data, and the $\mathrm{P} \leq 0.05$ results were considered significant. The Tukey HSD difference procedure was used to discriminate among the means.

\section{Results and discussion}

Table 1 presents the assessment of all of the physical, chemical and microbiological parameters that were indicators of loss of freshness, assessed in terms of storage time in the gutted tilapia. Almost all of the parameters assessed presented statistically significant differences $(\mathrm{P} \leq 0.05)$ as storage time increased, indicating a loss of freshness in the fish. For the case of ungutted tilapia, the evolution of the evaluated parameters based on storage time on ice is presented in Table 2. In the

Table 1. Evolution of gutted red tilapia on ice.

\begin{tabular}{lccccccc}
\hline \multicolumn{7}{c}{ Gutted tilapia } \\
Day & 0 & 3 & 5 & 8 & 11 & 14 & 17 \\
\hline Fillet & & & & & & & \\
Moisture (\%) & $74.47 \pm 1.54 \mathrm{a}$ & $76.33 \pm 20.01 \mathrm{a}$ & $78.33 \pm 1.53 \mathrm{a}$ & $77.33 \pm 0.58 \mathrm{a}$ & $77.00 \pm 1.00 \mathrm{a}$ & $76.33 \pm 0.58 \mathrm{a}$ & $77.00 \pm 0.00 \mathrm{a}$ \\
$\mathrm{pH}$ & $6.09 \pm 0.05 \mathrm{a}$ & $6.25 \pm 0.04 \mathrm{~b}$ & $6.45 \pm 0.10 \mathrm{c}$ & $6.46 \pm 0.05 \mathrm{c}$ & $6.41 \pm 0.04 \mathrm{c}$ & $6.45 \pm 0.04 \mathrm{c}$ & $6.51 \pm 0.03 \mathrm{c}$ \\
WHC (\%) & $91,27 \pm 1.54 \mathrm{a}$ & $90.02 \pm 4.44 \mathrm{a}$ & $79.35 \pm 4.49 \mathrm{~b}$ & $79.64 \pm 2.70 \mathrm{~b}$ & $63.25 \pm 1.75 \mathrm{c}$ & $56.65 \pm 3.68 \mathrm{c}$ & $55.87 \pm 3.15 \mathrm{c}$ \\
$\begin{array}{l}\text { Aerobic } \\
\text { mesophilic } \\
\text { bacteria (Log }\end{array}$ & $4.63 \pm 0.23 \mathrm{a}$ & $6.78 \pm 0.63 \mathrm{ab}$ & $6.60 \pm 1.17 \mathrm{ab}$ & $8.43 \pm 1.80 \mathrm{bc}$ & $7.81 \pm 1.35 \mathrm{bc}$ & $8.61 \pm 1.24 \mathrm{bc}$ & $9.67 \pm 1.98 \mathrm{c}$ \\
CFU g ${ }^{-1}$ ) & & & & & & & \\
\hline
\end{tabular}

Different letters in the same line indicate statistically significant changes $(\mathrm{P} \leq 0.05) ; \bar{x} \pm \mathrm{S}$. 
same way as gutted tilapia, statistically significant changes $(\mathrm{P} \leq 0.05)$ were found as the storage time increased.

The results obtained in this study showed how the $\mathrm{pH}$ increased during the storage time. In the gutted tilapia, $\mathrm{pH}$ increased gradually from $6.09 \pm 0.05$ to $6.51 \pm 0.03$ during the 17 days of storage (Table 1), whereas in the ungutted tilapia, the $\mathrm{pH}$ increased from $6.24 \pm 0.13$ to $6.44 \pm 0.06$ (Table 2). This ascending evolution was also recorded by Jain et al. (2007) in rohu and labeo carp, with values that were very similar to those obtained in this study ( $\mathrm{pH}$ of 6.1 to 6.9 ). The authors explained the result as a consequence of tissue exhaustion. A similar evolution was reported by Rodríguez et al. (2004), who recorded a change in the $\mathrm{pH}$ of hake stored in ice from 6.67 to 6.98 and 7.71 after 5 days and 19 days of storage, respectively. The same result was also reported by Ocaño-Higuera et al. (2011) for ray fish, with a $\mathrm{pH}$ that increased from 6.78 to 7 . The authors considered that the variation between the initial and final $\mathrm{pH}$ values may have been due to the species, the season when the fish was caught, its diet, the level of activity or stress during capture and the type of muscle tissue. The increased $\mathrm{pH}$ also indicated the accumulation of alkaline compounds, such as ammonia and trimethylamine (TMA) compounds, derived from the microbial action (FAO, 1995; Rodríguez et al., 2004).
The WHC, which measures the muscle's ability to retain free water, progressively diminished during storage time in both gutted and ungutted tilapia, but it was more evident in the gutted tilapia. The reduction of water holding capacity meant that an increased amount of water was exuded from the fish fillets. This lead to a loss of juiciness, which is important for both the industry and the consumer (Huss, 1988; Olsson et al., 2003; Olsson et al., 2007). For the gutted tilapia, an initial value of $90.02 \pm 4.44 \%$ and a final value of $55.87 \pm 3.15 \%$ were obtained on day 17 of storage in ice. A similar evolution was recorded by Ocaño-Higuera et al. (2011), who found a reduction in the water holding capacity in ray fish from an initial value of $92 \%$ to $87 \%$ during 18 days of storage in ice. This reduction was attributed the loss of functionality in the myofibrillar proteins responsible for water holding in muscles (Ocaño-Higuera et al., 2011), which could also be related to proteolytic activity in the muscles (Olsson et al., 2003). The magnitude of the change in the water holding capacity depended on the original conditions of the muscle (Ocaño-Higuera et al., 2006).

In the ungutted tilapia, the behavior of the measurements obtained reflected a significant change, given that the initial water holding capacity presented a value of $56.22 \pm 3.48 \%$, and on the sixth day, this increased to $67.51 \pm 4.34 \%$. This property diminished at 14 days to $54.52 \pm 5.14 \%$, and on the

Table 2. Evolution of ungutted red tilapia on ice.

\begin{tabular}{lccccccc}
\hline \multicolumn{7}{c}{ Ungutted tilapia } \\
Day & 0 & 3 & 6 & 9 & 11 & 14 & 16 \\
\hline Fillet & & & & & & & \\
Moisture (\%) & $76 \pm 1.73 \mathrm{a}$ & $76.33 \pm 1.15 \mathrm{a}$ & $77.33 \pm 0.58 \mathrm{a}$ & $77.33 \pm 0.58 \mathrm{a}$ & $77.67 \pm 0.58 \mathrm{a}$ & $77.67 \pm 0.58 \mathrm{a}$ & $77.67 \pm 0.58 \mathrm{a}$ \\
$\mathrm{pH}$ & $6.24 \pm 0.13 \mathrm{a}$ & $6.33 \pm 0.03 \mathrm{a}$ & $6.25 \pm 0.08 \mathrm{a}$ & $6.40 \pm 0.10 \mathrm{a}$ & $6.19 \pm 0.03 \mathrm{a}$ & $6.28 \pm 0.03 \mathrm{a}$ & $6.44 \pm 0.06 \mathrm{a}$ \\
$\mathrm{WHC}(\%)$ & $56.22 \pm 3.48 \mathrm{ab}$ & $66.19 \pm 4.27 \mathrm{c}$ & $67.51 \pm 4.34 \mathrm{c}$ & $51.58 \pm 2.82 \mathrm{a}$ & $53,84 \pm 2.54 \mathrm{ab}$ & $54.52 \pm 5.14 \mathrm{ab}$ & $60.61 \pm 2.39 \mathrm{bc}$ \\
$\begin{array}{l}\text { Aerobic } \\
\text { mesophilic } \\
\text { bacteria }\end{array}$ & $4.05 \pm 0.70 \mathrm{a}$ & $7.33 \pm 1.07 \mathrm{bc}$ & $7.14 \pm 1.60 \mathrm{~b}$ & $6.53 \pm 0.81 \mathrm{~b}$ & $7.31 \pm 1.15 \mathrm{bc}$ & $8.35 \pm 1.08 \mathrm{bc}$ & $9.29 \pm 1.04 \mathrm{c}$ \\
\begin{tabular}{l} 
(Log CFU g-1) \\
\hline
\end{tabular} & & & & & & & \\
\hline
\end{tabular}

Different letters in the same line indicate statistically significant changes $(\mathrm{P} \leq 0.05) ; \bar{x} \pm \mathrm{S}$. 
final day of sampling (day 16), the water holding capacity was reported as $60.61 \pm 2.39 \%$. This behavior of an ascending water holding capacity was also recorded by Olsson et al. (2003) in halibut cooled to $0{ }^{\circ} \mathrm{C}$, suggesting that the meat's water holding capacity improved with time and as a result of the structural changes to the proteins in the muscle or a post mortem expansion of the myofibrils (Moeseke and De Smet, 1999).

A detailed observation of the evolution of fish fillets showed that the microorganisms exceeded the 6 logarithmic cycles of aerobic mesophilic bacteria counts over 8 days, which was considered a limit consumption value for this food according to the European norm (CE) N 2074/2005 (CEE, 2005). On day 8 , the fish fillets experienced a statistically significant decrease in the water holding capacity, which indicated that besides the possibility of causing health problems, the fillet also lost sensorial properties that were attractive to the consumer, such as its juiciness. After the storage process, the aerobic mesophilic bacteria count was $9 \pm 1.98$ $\log$ CFU g ${ }^{-1}$ in the gutted tilapia at 17 days and $9 \pm 1.04 \mathrm{Log} \mathrm{CFU} \mathrm{g}^{-1}$ in the ungutted tilapia at 16 days. These results supported the use of gutted tilapia for its commercialization, recommending up to 8 days of alternating refrigeration and storage in ice to prolong its shelf life to guarantee quality (Lougovois et al., 2003; Erikson et al., 2011). The values obtained, according to Liston (1980) and cited by FAO (1995) and Olafsdottir et al. (1997), were typical values, given that the presence of microorganisms on the skin surface vary within a range of $2-7 \mathrm{Log} \mathrm{CFU} \mathrm{cm} \mathrm{cm}^{-2}$, and on the gills and gut they are normally within a range of 3 - $9 \mathrm{Log}_{\mathrm{CFU} \mathrm{g}}{ }^{-1}$ (FAO, 1995), which can extend to other tissues where there are nutritional substances and a relatively high $\mathrm{pH}$ that favor their development (Huss, 1995, cited by Massa, 2006).

The results of the present research study were similar to those found by Cardenas et al. (2007), who identified viable microorganism counts in cod fillets refrigerated at $\left(0-1^{\circ} \mathrm{C}\right)$ at $5 \mathrm{Log} \mathrm{CFU}$ $\mathrm{g}^{-1}$ at the beginning of the process and $9 \mathrm{Log}$
CFU g ${ }^{-1}$ during 14 days of storage. Similarly, Pons-Sánchez-Cascado (2005) determined initial and final aerobic mesophilic bacteria counts for anchovy of $4 \mathrm{Log} C F U ~ g^{-1}$ and $8 \log \mathrm{CFU} \mathrm{g}{ }^{-1}$, respectively, during storage on ice. Paleologos et al. (2004) determined an initial total viable count in gutted sea bass of $4 \mathrm{Log}_{\mathrm{CFU} \mathrm{g}}{ }^{-1}$ and a total viable count of $8 \mathrm{Log}_{\mathrm{CFU} \mathrm{g}}{ }^{-1}$ after 16 days of storage. In studies undertaken in Japan with salmon (Pseudopercis semifasciata), the aerobic count was less than $4 \log \mathrm{CFU} \mathrm{g}^{-1}$ in a good quality fish, bearing in mind that for raw fish, the maximum limit was $7 \log \mathrm{CFU} \mathrm{g}{ }^{-1}$, according to International Commission on Microbiological Specification for Foods (ICMSF) of the University of Toronto (Sallam, 2007). However, authors, such as Chytiri et al. (2004), determined that whole freshwater ungutted rainbow trout stored on ice presented a mesophyll count of $2.5 \mathrm{log}$ CFU cm$~^{-2}$ to $7.0 \log$ CFU cm$~_{-2}$ after 18 days of storage. This was very similar to the results found by Cakli et al. (2007) for bream, which obtained a total mesophyll count of $2.61 \pm 0.12 \mathrm{Log}$ CFU $\mathrm{g}^{-1}$ initially and a count of $7.97 \pm 0.04 \mathrm{Log}$ CFU $\mathrm{g}^{-1}$ after 18 days of storage. They also found that the sea bass presented a total mesophyll count of $2.78 \pm 0.07 \mathrm{Log}^{\mathrm{CFU} \mathrm{g}}{ }^{-1}$ initially and a count of $8.04 \pm 0.07 \mathrm{Log}_{\mathrm{CFU} \mathrm{g}}{ }^{-1}$ after 18 days of storage. The viable microorganism counts found in our study were different because the bacterial flora in a recently caught fish depended more on the environment where it was caught rather than the species itself (FAO, 1995; Gram and Huss, 1996). As mentioned above, species caught in very cold, clean waters had fewer microorganisms than those caught in warm waters, such as the tilapia in this study. This happened because the conditions of the warmer water were ideal for the growth of mesophilic microorganisms.

For ungutted tilapia, a loss of freshness that limited the consumption of the food was found three to six days after beginning storage in ice, with mesophyll aerobic bacteria total count values of $7.33 \pm 1.07$ Log CFU g ${ }^{-1}$ and $7.14 \pm 1.60 \mathrm{Log}$ CFU $\mathrm{g}^{-1}$, respectively. Similarly, the reduction of firm- 
ness in the fillets and abdomen were noticeable after the third day of storage. The evolution of the aerobic mesophilic bacteria counts allowed us to define the shelf life of the food in terms of days. For the case of gutted tilapia, on day 8 of refrigerated storage, the 6 logarithmic cycles established in the European legislation as the limit for the consumption of the fish were exceeded.
For the case of ungutted tilapia, the shelf life was shorter by three days of storage in ice, considering the same limit value in the bacterial count. The microbiological results allowed us to verify the use of gutted tilapia for its commercialization, recommending up to 8 days of alternating between refrigeration and storage in ice to prolong its shelf life, thus guaranteeing its good quality.

\section{Resumen}

Y.L. Ruiz-Osorio, C.M. Amorocho-Cruz y N. Gutíerrez-Guzmán. 2015. Cambios fisicoquímicos y microbiológicos en la Tilapia Roja (Oreochromis ssp) eviscerado y sin eviscerar, almacenada en hielo. Cien. Inv. Agr. 42(2):263-272. Se evaluó el grado de frescura del producto a través de métodos físicoquímicos y microbiológicos, realizando un muestreo durante los días $0,3,5,8,11,14$ y 17 en la Tilapia Roja eviscerada y en los días 0, 3, 6, 9, 11, 14, y 16 en la Tilapia Roja, sin eviscerar, con un tamaño de muestra de cinco peces almacenado en hielo bajo condiciones de refrigeración (0-4 $\left.{ }^{\circ} \mathrm{C}\right)$. El grado de frescura se estudió a través de diferentes métodos: $\mathrm{pH}$, capacidad de retención de agua (CRA) y análisis microbiológico (recuento de mesófilos aerobios). Obtenidos los resultados, se realizó un análisis de varianza simple (ANOVA) para determinar la posible correlación de los valores de deterioro y los datos obtenidos por métodos analíticos. El análisis de varianza simple arrojó que en casi todos los parámetros evaluados se presentaron diferencias estadísticamente significativas $(\mathrm{P} \leq 0.05)$ a medida que avanzó el almacenamiento, siendo un indicativo de la pérdida de frescura en el pescado. Es así como en la tilapia eviscerada, la evolución de la dureza del filete y del pescado entero, se encontraron descensos estadísticamente significativos más notorios en el octavo día de almacenamiento, momento a partir del cual fueron superados los seis ciclos logarítmicos en recuento de Mesófilos aerobios; este mismo día el filete experimentó un descenso estadísticamente significativo en la CRA. En la Tilapia sin eviscerar, la pérdida de frescura que limita el consumo del alimento se presentó entre los tres y seis días de iniciado el almacenamiento con valores en el recuento de Mesófilos aerobios de 7.33 $\pm 1.07 \mathrm{Log}_{\mathrm{UFC} \mathrm{g}}{ }^{-1}$ y $7.14 \pm 1.60 \mathrm{Log}$ $\mathrm{UFC}^{-1}$, respectivamente; de la misma forma, los descensos significativos en dureza del filete y dureza del vientre se hicieron notorios a partir del tercer día de almacenamiento.

Palabras clave: Almacenamiento, capacidad de retención de agua, CRA, peces, pH, mesófilos aerobios.

\section{References}

Adams, Mr., and M.O. Moss. 1997. Pescado. Alteración del pescado fresco. p. 153 -156. In: Mr. Adams (ed.). Microbiología de los alimentos. Acriba S.A. Zaragoza, España.

AENOR-Asociación Española de Normalización y Certificación. 2004. Norma UNE EN-ISO 6887-3
Microbiología de alimentos para consumo humano y animal. Preparación de las muestras de ensayo, suspensión inicial y diluciones decimales para el examen microbiológico. Parte 3: Reglas específicas para la preparación de pescados y productos de la pesca. Edit. AENOR. Madrid, España. 10 pp. Ayala, M.D., I. Abdel, M. Santaella, C. Martínez, M. Periago, F. Gil, A. Blanc., and O. López. 2010. 
Muscle tissue structural changes and texture development in sea bream, Sparus aurata L., during post-mortem storage. LWT - Food Science and Technology 43: 465-475.

Barros-Velázquez, J., J.M. Gallardo, P. Calo, and P. Aubourg. 2008. Enhanced quality and safety during on-board chilled storage of fish species captured in the Grand Sole North Atlantic fishing bank. Food Chemistry 106: 493-500.

Cakli, S., B. Kilinc, A. Cadun, T. Dincer, and S. Tolasa. 2007. Quality differences of whole ungutted sea bream (Sparus aurata) and sea bass (Dicentrarchus labrax) while stored in ice. Food Control 18:391-397.

Cardenas, A., K. Sveinsdottir, and E. Martinsdottir. 2007. Development of Quality Index Method (QIM) scheme for fresh cod (Gadus morhua) fillets and application in shelf life study. Food Control 18:352-358.

CEE. 2005. Reglamento (CE) no 2074/2005 de la Comisión de 5 de diciembre de 2005 por el que se establecen medidas de aplicación para determinados productos (...). Sección II, Capítulo I: Valores límite de nitrógeno básico volátil total (NBVT) para determinadas categorías de productos de la pesca y métodos de análisis que deberán utilizarse. Diario Oficial de la Unión Europea, L338, 36.

Chebet, L. 2010. "Rapid" (alternative) methods for evaluation of fish freshness and quality. Masters Thesis. University of Akureyri. Faculty of Business and Science. Department of Natural Resource Sciences and United Nations University. Akureyri, Island. 66 pp.

Chytiri, S., I. Chouliara, I.N. Savvaidis, and M.N. Kontominas. 2004. Microbiological, chemical and sensory assessment of iced whole and filleted aquacultured rainbow trout. Food Microbiology 21:157-165.

Erikson, U., E. Misimi, and L. Gallart-Jornet. 2011. Superchilling of rested Atlantic salmon: Different chilling strategies and effects on fish and fillet quality. Food Chemistry 127:1427-1437.

FAO. 1995. El pescado fresco su calidad y cambios de su calidad. Available online at: http://www. fao.org/DOCREP/V7180E/V7180E00.HTM (Website accessed: March 28, 2013).
Fuentes, A., I. Fernandez-Segovia, J.A. Serra, and J.M. Barat. 2010. Comparison of wild and cultured sea bass (Dicentrarchus labrax) quality. Food Chemistry 119: 1514-1518.

García-Soto, B., S. Aubourg., P. Calo-Mata, and J. Barros-Velázquez. 2013. Extension of the shelf life of chilled hake (Merluccius merluccius) by a novel icing medium containing natural organic acids. Food Control 34:356 -363.

Gram, L., and H.H Huss. 1996. Microbilogical spoilage of fish and fish products. International Journal of Food Microbiology 33: 121-137.

Hernández, M.D., M.B. López., A. Álvarez., E. Ferrandini., B. García-García., and M.D. Garrido. 2009. Sensory, physical, chemical and microbiological changes in aquacultured meagre (Argyrosomus regius) fillets during ice storage. Food Chemistry 114: 237-245.

Hultmann, L., and T. Rustad. 2007.Effects of temperature abuse on textural properties and proteolytic activities during post mortem iced storage of farmed Atlantic cod (Gadus morhua). Food Chemistry 104: 1687-1697.

Huss, H.H. 1988. Cambios post-mortem en el pescado._In: Huss, H.H. (ed.). Colección FAO Pesca No 29, Roma, Italy. p. 61-75.

ICONTEC - Instituto Colombiano de Normas Técnicas y Certificación. 2009.Norma Técnica Colombiana NTC-4519. 2009. Técnica de recuento de colonias a $30^{\circ} \mathrm{C}$. Microbiología de los alimentos para consumo humano y animal. Método horizontal para el recuento de microorganismos. Bogotá, Colombia. 17 pp.

ICONTEC - Instituto Colombiano de Normas Técnicas y Certificación. 2005. Norma Técnica Colombiana NTC-4491-1. 2005. microbiología de alimentos y alimentos para animales. Preparación de muestras para ensayo, suspensión inicial y diluciones decimales para análisis microbiológico. Parte 1. Reglas generales para la preparación de la suspensión inicial y de diluciones decimales. Bogotá, Colombia. 7 pp.

ICONTEC - Instituto Colombiano de Normas Técnicas y Certificación. 2002. Guía Técnica Colombiana GTC 78. Guía para la preparación y producción de medios de cultivo. Guía general 
para el aseguramiento de la calidad para la preparación de los medios de cultivo en el laboratorio. Microbiología de alimentos y alimentos para animales. Bogotá. Colombia. 23 pp.

Jain, D., P. Pathare, and M.R. Manikantan. 2007. Evaluation of texture parameters of Rohu fish (Labeo rohita) during iced storage. Journal of Food Engineering 81: 336-340.

Li, T., J. Li, and W. Hu. 2013. Changes in microbiological, physicochemical and muscle proteins of post mortem large yellow croaker (Pseudosciaena crocea). Food Control 34: 514-520.

Liu, D., L. Liang., W. Xia, J. Regenstein, and P. Zhou. 2013. Biochemical and physical changes of grass carp (Ctenopharyngodon idella) fillets stored at -3 and $0{ }^{\circ} \mathrm{C}$. Food Chemistry 140: 105-114.

Lougovois, V., E. Kyranas, and V. Kyrana. 2003. Comparison of selected methods of assessing freshness quality and remaining storage life of iced gilthead sea bream (Sparus aurata). Food Research International 36:551-560.

Massa, A.E. 2006. Cambios bioquímicos post- mortem en músculo de diferentes especies pesqueras. Determinación de la vida útil de las mismas en frío. Tesis Doctoral. Departamento de Biología. Facultad de Ciencias Exactas y Naturales. Mar de Plata, Argentina. 219 pp.

Moeseke, W., and S. De Smet. 1999. Efect of time of deboning and sample size on drip loss of pork. Meat Science 52:151-156.

Ocaño-Higuera, V.M., A.N. Maeda-Martínez., E. Marquez-Ríos., D.F. Canizales-Rodríguez., F.J. Castillo-Yáñez., E. Ruíz-Bustos., A.Z Graciano-Verdugo, and M. Plascencia-Jatomea. 2011. Freshness assessment of ray fish stored in ice by biochemical, chemical and physical methods. Food Chemistry 125:49-54.

Ocaño-Higuera, V.M., A.N. Maeda-Martínez., M.E. Lugo-Sánchez, and R. Pacheco-Aguilar. 2006. Postmortem biochemical and textural changes in the adductor muscle of catarina scallop stored at $0^{\circ} \mathrm{C}$. Journal of Food Biochemistry 30:373-389.

Olafsdóttir, G., E. Martinsdbttir, J. Oehlenschbger, P. Dalgaard, B. Jensen, I. Undeland, I.M. Mackie, G. Henehan, J. Nielsen, and H. Nielsen. 1997. Methods to evaluate fish freshness in research and industry. Review. Trends in Food Science and Technology 81: 258-265.

Olsson, G., R. Ofstad., J. Lodemelc, and R. Olsen. 2003. Changes in water-holding capacity of halibut muscle during cold storage. LWT-Food Sci. Technol. 36:771-778.

Olsson, G.; M. Seppola and R. Olsen. 2007. Waterholding capacity of wild and farmed cod (Gadus morhua) and haddock (Melanogrammus aeglefi$n u s)$ muscle during ice storage. LWT-Foods Sci. Technol. 40:793-799.

Owen, J., F. Núñez, M. Arias, and O. Cano de los Ríos. 1981. Manual de Prácticas para cursos de tecnología de la carne. Facultad de Zootecnia. Universidad Autónoma de Chihuahua. Chihuahua, Chih., México. 132 pp.

Paleologos, E.K., I.N. Savvaidis, and M.G. Kontominas. 2004. Biogenic amines formation and its relation to microbiological and sensory attributes in ice-stored whole, gutted and filleted Mediterranean Sea bass (Dicentrarchus labrax). Food Microbiology 21:549-557.

Pérez J., E. Costell, M. Mingarro, S. Vega-Rubin, J.A. Calduch, M.L. Orlando, J. Rielo, M.J. Pujalte, E. Garay, A. Sitjà-Bobadilla, P. Alvarez Pellitero, L. Izquierdo Faubel, and L. Durán Hidalgo. 2002. Evaluación de la calidad sensorial. p. 65-86. In: Pérez, J. and E. Costell (eds.). Estrategias de alimentación y cultivo de la Dorada Estado patológico y control de la calidad sensorial. Instituto de agroquímica y tecnología de Alimentos (CSIC). Valencia, España. 108 pp.

Pons-Sánchez-Cascado, S. 2005. Estudio de alternativas para la evaluación de la frescura y la calidad del Boquerón (Engraulis encrasicholus) y sus derivados. Tesis Doctoral. Departamento de Nutrición y Bromatología. Facultad de Farmacia. Universidad de Barcelona. Barcelona, España. 270 pp.

Pons-Sánchez-Cascado, S., M.C. Vidal-Carou, M.L. Nunes, and M.T. Veciana-Nogues. 2006. Sensory analysis to assess the freshness of Mediterranean anchovies (Engraulis encrasicholus) stored in ice. Food Control 17:564-569.

Rodríguez, O., V. Losada., S. Aubourg, and J. BarrosVelazquez. 2004. Enhanced shelf-life of chilled European hake (Merluccius merluccius) stored 
in slurry ice as determined by sensory analysis and assessment of microbiological activity. Food Research International 37: 749-757.

Sallam, K. 2007. Antimicrobial and antioxidant effects of sodium acetate, sodium lactate, and sodium citrate in refrigerated sliced salmon. Food Control 18:566-575.
Simat, V., T. Bogdanovic, M. Krzelj, A. Soldo, and J. Marsic'-Lucic'. 2012. Differences in chemical, physical and sensory properties during shelf life assessment of wild and farmed gilthead sea bream (Sparus aurata L.). J. Appl. Ichthyol. 28: 95-101. 